\title{
CONTROL AND PROTECTION OF GARRISON EVENTS BY THE MILTARY POLICE UNITS
}

\section{KONTROLA I OCHRONA ZDARZEŃ GARNIZONOWYCH PRZEZ MILITARNE JEDNOSTKI POLICJI}

\author{
Simeon Andreev ${ }^{1}$ \\ VASIL LEVSKI NATIONAL MILITARY UNIVERSITY \\ BULGARIA
}

\begin{abstract}
Military police enable commanders to achieve their objectives by providing a unique set of capabilities that support joint functions and control functions over garrison events through the military police disciplines of police operations, detention operations, and security and mobility support. The aim of the article is to describe the military police support provided to Army forces and Police that are conducting unified garrison events within the framework of joint operations and increases the control and protection of such events and also defense support of civil authorities. The methodology includes descriptive analysis of the MP support to such joint operations.

Streszczenie: Żandarmeria wojskowa umożliwia dowódcom osiągnięcie ich celów poprzez zapewnienie unikalnego zestawu zdolności wspierających wspólne funkcje i funkcje kontrolne nad wydarzeniami garnizonowymi poprzez wojskowe dyscypliny policyjne operacji policyjnych, operacji zatrzymania oraz wsparcia w zakresie bezpieczeństwa i mobilności. Celem artykułu jest opisanie wsparcia żandarmerii wojskowej udzielanego siłom zbrojnym i policyjnym prowadzącym ujednolicone zdarzenia garnizonowe w ramach wspólnych działań oraz zwiększenie kontroli i ochrony tych zdarzeń, a także wsparcia obronnego władz cywilnych. Metodologia obejmuje opisową analizę wsparcia MP dla takich wspólnych operacji.
\end{abstract}

Keywords: military police support, public order, participants.

Słowa kluczowe: wsparcie żandarmerii wojskowej, porządek publiczny, uczestnicy.

1 Sergeant Simeon Andreev, Vasil Levski National Military University, Veliko Tarnovo, Bulgaria, speciality: national and regional security; e-mail: simonandreev@abv.bg.

Sierżant Simon Andreev, Narodowy Uniwersytet Militarny im. Vasyla Levskiego, Veliko Tarnovo, Bułgaria, specjalność: bezpieczeństwo narodowe i regionalne; e-mail: simonandreev@abv.bg. 


\section{Introduction}

The Military Police Service is a specialized structure for procuring the order and security in the Ministry of Defense, in the structures of direct subordination of the Minister of Defense and in the Bulgarian Army and it also is ensuring the security of their personnel. The Military Police Service is part of the Armed Forces, directly subordinate to the Minister of Defense. It acts alone or in cooperation with other security services for the protection of public order (Bulgarian military police Law, 2011, http://vp.mod.bg/bg/home.html).

\section{Legal bases}

1. Military Police Act (MPA)

- Article 2, paragraph 1, item 2, which reads "Military Police", performs the security activity for prevention, intercepting and protection against unlawful violations of persons, objects, property, armament equipment and events";

- Paragraph 3, "MPF in BA perform control and security activities in the garrisons and the deployment areas outside them, carrying out;

- control of the observance of the military order and the military discipline of the servicemen;

- protection, access control, access regime;

- escort of military vehicles;

- control over the use of military vehicles (Bulgarian military police Law, 2011).

2. Law enforcement regulations of the military police:

Article 11, paragraph 1, Security is a combination of actions and measures to prevent, intercept, protect against unlawful encroachments and ensure the physical security of persons, objects and events, but Article 7 (1) of the MPA („Bulgarian Law enforcement regulations of the military police”, 2017).

\section{General}

Ensuring the safety and security of public order in the conduct of garrison (mass) events aims to ensure the safety of officials, leadership and servicemen by preventing, crossing and uncovering crimes and public order violations. In addition, the staff is responsible for regulating and ensuring the safe movement of vehicles and pedestrians in the area of conducting the event. (Bulgarian military police Law, 2011)

When government officials, members of foreign military delegations and guests are present at garrison events, the main purpose of the security is to ensure their safety by preventing and intercepting terrorist and other possible unlawful acts. 
Depending on their character and content, the garrison (mass) events are:

- public - with participation of soldiers in various public, cultural and educational events in the garrisons (celebrations of anniversaries, holidays, rituals, etc.);

- military - with participation of military personnel in organized military activities with the presence of citizens (military oaths, parades, solemn inspections, iluminations, defense of battle flags, solemn celebration of Bulgarian army holidays,species and kinds of troops, etc.);

- sports - with the participation of soldiers in competitions and games (Bulgarian military police Law, 2011).

Depending on the scale of the events, the number and composition of the participants, they can be inter-national, regional, and garrison.

Ensuring the safety of the garrison (mass) activities is carried out with the full force and means of the military police forces in cooperation with the "Control and Guard" and the "Security Services of the Military Police Service" as well as the forces and resources of the National Police, National Security and Defense and others provided for participation in the event. In special cases, troops from the Armed Forces may also be requested or ordered by the head of the garrison (Bulgarian military police Law, 2011).

Apart from weapons, equipment, aids and special tools, the Military Police authorities may be provided with:

- portable enclosures - constraining strips, barriers, ropes, railings, etc.;

- $\quad$ sound systems - amplifiers, speakers, megaphones, etc.;

- video equipment, cameras, binoculars, metal detectors and explosive detection devices.

When providing the security for a garrison (mass) event, the area is divided into zones, sections, sectors and directions for separation and surveillance. (Bulgarian military police Law, 2011)

Created:

1. Military police cordon (MPC) - an area cleavage group in order to avoid uncoordinated access to it, creation of guiding corridors providing the movement of columns as well as distinguishing rectangles of the places for displacement of participants and spectators in mass events. (Arabadjiyski, N., "Police administration", S., 2002).

Cordon can be:

- ordinary - when the staff is lined up at a distance of 1-2 meters a person from person;

- reinforced - when the staff is lined up at a distance of 1 meter

- diluted - when the staff is positioned at a distance of more than 2 meters.

The cordon can only be deployed by Military Police or it can be mixed. (Arabadjiyski, N., "Police administration", S., 2002). 
2. Shelter (AU) - a squadron consisting of a sub-division (group of employees) of the Military Police who perform tasks of blocking a certain area or of cover (fencing) a separate direction in order to prevent entry / exit into or out of them, for people animals and vehicles (Arabadjiyski, N., "Police administration”, S., 2002);

3. Control Entry Point (CEP) - a group to ensure the admission regime or to restrict the movement of vehicles and pedestrians in a particular area (streets, areas or sites) during mass events, in case of natural disasters, epidemics, etc. Separate officers are appointed on the most important sections and directions for senior officers of the CEP (Arabadjiyski, N., "Police administration", S., 2002);

4. Observation post (OP) - a group assigned to observe and inform in due time the progress of the event and the changes in the situation (Arabadjiyski, N., "Police administration", S., 2002).

\section{Organization of the activity}

The activity of ensuring the safety and security of the public order when conducting garrison events is divided into three periods: preparatory, executive and concluding.

1. In the preparatory period starting from the moment of receiving the task, the following shall be carried out:

The location, timing and order of the event, the quantity and composition of the participants and viewers shall be specified.

Scouting (if necessary), it is decided how to maintain the public order and safety, and a plan is developed.

The preliminary interaction with the authorities of the Ministry of Internal Affairs (MoIA), NSD, etc., involved in the security of the event is organized.

Additional measures are being taken to strengthen the fight against crime.

The personnel training and the technical means for the execution of the service are organized.

The places where the events are held are fireproof checked and inspected for the presence of explosives and other generally dangerous means.

In cooperation with the MoIA authorities, the vehicles parked at the place of its operation are removed. Measures shall be taken for additional equipment with security tools in the area where the event will be held in order to secure adjacent buildings, ceilings, cellars, lively junctions, etc. They instruct the personal about their duties in conducting the event (Bahchevanov, G., Karamfilov, G., „Legitimate use of military force in the prevention of conflicts and neutralizing modern asymmetric threats”, Military academy „G. S. Rakovski”).

The scouting of the area where the event is conducted is in order to study the peculiarities of the territory and the condition of the roads, to determine and specify the order of movement, the points of collection and placement 
of the personnel, the places of transport, forces and means, the setting of the groups and their duties, the boundaries of the zones, the sectors and sections of the escape, the location of the control entry points, the reserve and the means of maneuvering with the forces and vehicles during the ongoing event.

(Bahchevanov, G., Karamfilov, G., „Legitimate use of military force in the prevention of conflicts and neutralizing modern asymmetric threats", Military academy „G. S. Rakovski”).

On the basis of the made decision, a plan for the protection of public order and safety during the course of the event is elaborated. It includes:

Content of the event, timing, quantity and composition of the participants, armaments, equipment and form.

Event venue, boundaries, sectors and blocked sections, management posts.

Used forces and resources (how many forces and resources are attracted to the task, from which units, their layout, what tasks will they perform, tactics, maneuver with the forces and means during the event, providing a reserve).

Additional forces and means, their tasks and the order of interaction.

The order of traffic and pedestrian regulation, the movement routes of the participants and the viewers.

Organization of liaison (estimation of forces and means, organization of conduction and radio communication, TV monitoring, call sign and signals).

Organization of material, technical and medical insurance.

The public order maintenance plan shall be elaborated in a textual manner with the necessary calculations, tables, schedules and other working papers. The same is given in the form of an order in the report book, and after completing a task, areport memo prepared for the event is added (Bahchevanov, G., Karamfilov, G., „Legitimate use of military force in the prevention of conflicts and neutralizing modern asymmetric threats”, Military academy „G. S. Rakovski”).

For the management of the forces and means during the preparation and the conducting of the mass event, a management group is established. The numbers, composition and tasks are determined by the nature, scale and importance of the mass event.

The management of the forces and means during the implementation of the events is carried out by "specially organized management posts where workplaces are being prepared". The management posts are created directly in the area for the event and are located in places where the forces and means can best be managed. They can be mobile and stationary. Each management post shall be provided with the necessary means of communication.

The preparation of the personnel for the performance of the service is ensured by conducting meetings with the managerial staff, instruction of the classes 
and trainings. If necessary, special classes are organized, with special attention being paid to the practical carrying of the service (Arabadjiyski, N., "Police administration", S., 2002).

At the meetings and briefings of the groups, the program of the event is explained, using a scheme of the area and other visual aids. It specifies the participants in the provisioning, the sectors, the directions and the routes for movement of people and vehicles, the location of the management points, the reserves, the medical stations, the fire-fighting machines (tools), the trade pavilions, the sanitary units and the ones with the samples of omissions documents entitling entry into the blocked area (Arabadjiyski, N., "Police administration", S., 2002).

Trainings are held directly at the location to conduct it as planned. They specify the tasks, the places of focus and layout of the ranks, the boundaries of the sectors, the sections and the directions. The reality of the established time limits for the deployment of forces and means is checked. Practice drills are carried out on maneuvering and planned rebuilding. Checking the readiness and flexibility of the power and resource management system and the organization of interaction (Arabadjiyski, N., "Police administration", S., 2002).

In the event of garrison events, all types of exercises provided in the present methodology are used to solve the assigned tasks.

Reserves are located in places where they can be put into action as quickly as possible. A maximum of $15 \%$ of all security forces and resources may be assigned to the reserve of the senior deputy. The reserves at the disposal of the heads of sectors, divisions, or strands make up 10-15\% of the forces and means used to perform the service in the given sector, division or direction. Expended reserves are immediately reimbursed at the expense of the released forces and funds from the less important sections and directions.

If necessary, the Chief of Staff may, after consultation with relevant organizations and local authorities, suspend the movement of vehicles and pedestrians for a certain period of time, completely or partially alter the direction of movement, and also temporarily suspend the operation of commercial and other enterprises and establishments falling within the area of exclusion.

2. The implementation period covers the actions during the event. During this period the following activity is carried out:

- introduces the planned traffic and pedestrian traffic restrictions.

- citizens not participating in the events are taken out of the cut-off zone.

3. The execution of the duties of the personal shall be organized in the area of the events and the adjacent territories (Arabadjiyski, N., "Police administration", S., 2002). 


\section{Employee competencies}

The groups are put into action depending on the progress of the event, and when they are no longer needed, they are taken into the reserves or used to perform other tasks, at the command of the chief boss.

At the time of the event, the staff of the groups must:

- to be in the defined area and without explicit permission not to leave it;

- to know and skillfully perform the tasks and instructions;

- not to allow persons who do not have relevant documents in the cut-off area.

The personnel performing security services in the presence of governmental delegations, officials, guests from abroad and others shall be obliged to:

- to monitor the order in the block, the column, the sector, the hall;

- to prevent the flow of flowers and other objects towards the members of the delegation, as well as the passage of citizens through the barriers (ropes, railings, etc.);

- to close the places where the itinerary crosses highways, busy intersections and others to pass citizens and vehicles at the time;

- in the passage of the delegation to face the citizens, vigilantly and with caution to monitor all the actions in the sector for which he is responsible. At this point, the uniformed team does not pay tribute to it;

- the posts behind the cordon, in the hall, on the tribunes observe the behavior and actions of the citizens and, if necessary, immediately intercept any attempt to break the established order;

- citizens living or working in the cut-off area are skipped to their dwellings by presenting a passport or other document certifying that they live there and at the place of work on the basis of a document of employment;

- a further omission line may be established by decision of the Chief of Staff. It is forbidden to enter the blocked zone:

- drunk or alcohol-bearing and visually mentally ill persons;

- persons carrying weapons, dangerous goods, bags, trunks or large packets.

Exceptionally, persons in possession of large packets, bags or suitcases may be missing in the area of confinement to their place of residence or place of work. In these cases, they only cross the border crossing point and are accompanied by military police officers.

The groups are required to exercise special observability when performing the service during the course of the event. In any case or conditions they must act calmly and confidently, preventing any panic and disorder.

Those intoxicated and mentally ill are immediately removed from the event area.

Upon the elimination of the necessity, the restrictions imposed on the movement of the traffic and the pedestrians ordered by the chief of staff shall be canceled. 
In conducting sporting competitions, the groups perform the following tasks:

- prior to the start of the competition, they ensure the order at the entrances of the sports facility and prevent the import of alcohol, weapons and other dangerous objects from viewers;

- during the competition - they guard the rows of the stands, do not allow the selling of alcohol to the spectators and go out on the field where the competition is held.

After completing the competition - they ensure the organized exit of the spectators from the sports base. (Arabadjiyski, N., "Police administration", S., 2002).

\section{Conclusion}

From this study we can make the following conclusion that providing public order in the conduct of garrison events is a compulsory activity ensuring the order and observance of the established rules and laws acting on the territory of the Republic of Bulgaria.

The actions of the Military Police and Military Police Forces in ensuring the safety of the public order in the conduct of garrison events regulated by the Military Police Act and its Implementing Rules in full ensure the security of the personnel, equipment and armaments of the participants.

In this order it is important and especially valuable continuous preparation and improvement of the specific skills and abilities of military officers from the Military Police Formations by the Armed Forces of the Bulgarian Army of the Republic of Bulgaria.

The Military Police Service, as an essential part of the security and public order sector of the country, supports the establishment of law and order, counteracts crime and other forms of anti-social activity, and provides real prevention and training of the armed forces personnel.

The establishment of the Military Police Service as a regional leader in the use of military capabilities is an opportunity to raise the reputation of the Republic of Bulgaria in the Euro-Atlantic community and to enhance the role of the country in maintaining security in the region.

The vision is an open and flexible document that will develop according to the development of the armed forces of the Republic of Bulgaria and the changing external and internal factors of the security environment. 


\section{REFERENCES}

[1] Bulgarian military police Law, 2011.

[2] „Bulgarian Law enforcement regulations of the military police”, 2017.

[3] Statute for the military service of the armed forces of the Republic Bulgaria.

[4] Arabadjiyski N., "Police administration", S., 2002.

[5] Bahchevanov G., Karamfilov G., Legitimate use of military force in the prevention of conflicts and neutralizing modern asymmetric threats, Military academy „G. S. Rakovski”.

[6] http://vp.mod.bg/bg/home.html. 
